\title{
The Hydroxyl Radical Generated by an Iron(II)/EDTA/Ascorbate System Preferentially Attacks Tryptophan Residues of the Protein
}

\author{
Koji UCHIDA, * Naoki EnOMOTo, Koichi ITAKURA \\ and Shunro KaWAKISHI \\ Department of Food Science \& Technology, Nagoya University, \\ Nagoya 464-01, Japan \\ Received July 10, 1989
}

\begin{abstract}
Iron(II)/EDTA/ascorbate-mediated oxidative damage to specific amino acid residues (tryptophan) of serum albumin was studied. The active species generated by Fe(II)/EDTA/ascorbate preferred to react with tryptophan residues rather than histidine or other amino acids. The observation of preferential damage to tryptophan residues of the protein was fully suported by a model experiment using a tryptophan analogue. The reaction of Fe(II)/EDTA/ascorbate to the protein was significantly suppressed by mannitol and dimethysulfoxide, suggesting the participation of the hydroxyl radical generated via Fenton's reaction. The result was supported by the hydroxyl radical assay using 2deoxyribose.
\end{abstract}

Ascorbate is definitely an essential compound present at high concentrations in some mammalian tissues such as adrenals, leucocytes, brain, eyes, and pneumocytes. ${ }^{1)}$ As a reductant in food and biological systems, ascorbate by itself has been the focus of numerous basic studies. ${ }^{2 \gamma}$ However, the beneficial roles of ascorbate have focused attention also on its involvement in detrimental processes, which might be mostly attributed to the autoxidation of ascorbate by itself. ${ }^{3)}$

Ascorbate is relatively stable in pure water, while in the presence of catalytic amounts of metal ion, it is rapidly oxidized to dehydroascorbate through an electron-transfer from ascorbate to metal. ${ }^{4 \sim 6)}$ The rate of reaction is known to depend on $\mathrm{pH}$, catalyst, oxygen pressure, temperature, etc. The function of ascorbate is to reduce the metal ion $[\mathrm{M}(n+1)](\mathrm{Eq} .(1))$, and to serve as a source for superoxide $\left(\mathrm{O}_{2}{ }^{-}\right)$(Eq. (2)) and hydrogen peroxide $\left(\mathrm{H}_{2} \mathrm{O}_{2}\right)(\mathrm{Eq}$. (3)). The reduced metal ion $[\mathrm{M}(n)]$ is conducted via a Fenton's reaction to generate the most potent oxidant, the hy- droxyl radical ('OH) (Eq. (4))

$$
\begin{aligned}
& \mathrm{M}(n+1)+\text { ascorbate } \\
& \quad \rightarrow \mathrm{M}(n)+\text { dehydroascorbate } \\
& \mathrm{M}(n)+\mathrm{O}_{2} \rightarrow \mathrm{M}(n+1)+\mathrm{O}_{2}{ }^{-} \\
& \mathrm{O}_{2}{ }^{-}+2 \mathrm{H}^{+} \rightarrow \mathrm{H}_{2} \mathrm{O}_{2} \\
& \mathrm{M}(n)+\mathrm{H}_{2} \mathrm{O}_{2} \rightarrow \mathrm{M}(n+1)+\mathrm{OH}^{-}+{ }^{\cdot} \mathrm{OH}
\end{aligned}
$$

Accordingly, the cytotoxicity of ascorbate in the presence of metal ions has been interpreted in terms of the generation of oxygen-derived free radicals. ${ }^{7)}$

In vitro, a metal/ascorbate system promotes the oxidative scission of various food and biological materials such as polysaccharides, ${ }^{8}$ ) proteins, ${ }^{7,9 \sim 14)}$ and $\mathrm{DNA}^{15)}$ and also mediates the specific oxygenation of a histamine analogue. ${ }^{16)}$ Especially, it is of a great interest that this system gives rise to the specific modification of histidine residues of the protein. ${ }^{10 \sim 14)}$ We have confirmed that approximately $60 \%$ of histidine residues of the protein and peptides were selectively modified

* To whom correspondence should be addressed. 
within $24 \mathrm{hr}$ through the reaction with the $\mathrm{Cu}(\mathrm{II}) /$ ascorbate system. ${ }^{13,14)}$ In relation to this, we have found that active species generated by $\mathrm{Fe}(\mathrm{II}) / \mathrm{EDTA} /$ ascorbate preferentially attack tryptophan residues rather than histidine residues of the protein (K. Uchida, et al., unpublished results).

In this study, we have mainly focused on the reactivity of $\mathrm{Fe}(\mathrm{II}) / \mathrm{EDTA} /$ ascorbate with the tryptophan residues of the protein, compared with $\mathrm{Cu}(\mathrm{II}) /$ ascorbate. The results indicate that tryptophan residues of the protein and their analogue are particularly susceptible to oxidation by a $\mathrm{Fe}(\mathrm{II}) / \mathrm{EDTA} /$ ascorbate system.

\section{Materials and Methods}

Materials. L-Ascorbic acid, ferrous sufate $\left(\mathrm{FeSO}_{4}\right.$. $7 \mathrm{H}_{2} \mathrm{O}$ ), dimethylsulfoxide, 2-deoxy-D-ribose, 2-thiobarbituric acid, and mannitol were purchased from Wako Pure Chemical Industries Ltd. (Osaka), and bovine serum albumin from Seikagaku Kogyo Co., Ltd. (Tokyo). NBenzoyl-L-histidine and $N$ - $t$-butoxycarbonyl-L-tryptophan were obtained from the Sigma Chemical Company. Trifluoroacetic acid $(>99 \%)$ was purchased from Tokyo Kasei Kogyo Co., Ltd. All other reagents were of the highest grade comercially available.

Reaction of bovine serum albumin with $F e(I N)$ /EDTA/ascorbate. Reaction mixtures $(2.5 \mathrm{ml})$ containing $0.04 \%(\mathrm{w} / \mathrm{v})$ bovine serum albumin, $5 \mathrm{~mm}$ ascorbate, $50 \mu \mathrm{M} \mathrm{FeSO}$, and $50 \mu \mathrm{m}$ EDTA in $0.1 \mathrm{~m}$ phosphate buffer ( $\mathrm{pH} \mathrm{7.2)} \mathrm{were} \mathrm{incubated} \mathrm{at} \mathrm{room} \mathrm{temperature.} \mathrm{After}$ incubation, the reaction was stopped by the addition of $12 \%$ trichloroacetic acid $(2.5 \mathrm{ml})$, and the precipitated protein was collected by centrifugation $(3000 \mathrm{rpm}, 20 \mathrm{~min})$.

The protein was analyzed by HPLC on a TSK-GEL G3000 SW column $(7.5 \times 600 \mathrm{~mm})$. Samples were eluted at a rate of $1.0 \mathrm{ml} / \mathrm{min}$ with $0.1 \mathrm{M}$ phosphate buffer, $\mathrm{pH} 7.0$, containing $0.1 \mathrm{M} \mathrm{NaCl}$, the elution being monitored continuously at $210 \mathrm{~nm}$.

Slab gels of $10 \%$ acrylamide, and Tris-glycine electrophoresis buffer were prepared as described by Davis. ${ }^{17)}$ Gel sheets were stained with a solution of $0.2 \%$ Coomassie Brilliant Blue R-250 in water-2-propanol-acetic acid $(5: 5: 1, \mathrm{v} / \mathrm{v} / \mathrm{v})$ and destained with $7 \%$ acetic acid containing $10 \%$ methanol.

Amino acid analysis of native and oxidized bovine serum albumin was done with a JEOL JLC-6AH amino acid analyzer, for which the samples were prepared as follows: the protein collected by centrifugation was hydrolyzed with $6 \mathrm{~N} \mathrm{HCl}(1.5 \mathrm{ml})$ at a concentration of $2 \mathrm{mg}$ protein $/ \mathrm{ml}$ at $120^{\circ} \mathrm{C}$ for $24 \mathrm{hr}$. The hydrolyzates were concentrated, dissolved in $6 \mathrm{ml}$ of aqueous $\mathrm{HCl}(\mathrm{pH} \mathrm{2.2)}$, and then used for the analysis.

On the other hand, time-dependent change in the tryptophan content of the protein during incubation with $\mathrm{Fe}(\mathrm{II}) / \mathrm{EDTA} /$ ascorbate was measured by the native fluorescence of protein, with a JASCO FP-550A spectrophotometer, by the method of Gutteridge and Wilkins. ${ }^{18)}$ For this the sample proteins were collected by precipitation with $12 \%$ trichloroacetic acid, dissolved with $0.1 \mathrm{M}$ phosphate buffer $(5 \mathrm{ml})$, and their native fluorescence was measured with excitation at $280 \mathrm{~nm}$ and emission at $340 \mathrm{~nm}$.

Reaction of the histidine derivative with $\mathrm{Fe}(I)$ /EDTA/ascorbate. The histidine derivative, $N$-benzoylhistidine, was oxidized by incubating $1 \mathrm{mM} \mathrm{N}$-benzoylhistidine in $0.1 \mathrm{M}$ phosphate buffer $(\mathrm{pH} 7.2,10 \mathrm{ml})$ containing $5 \mathrm{~mm}$ ascorbate, $50 \mu \mathrm{M} \mathrm{FeSO}_{4}$, and $50 \mu \mathrm{m}$ EDTA. The samples were incubated at room temperature. $N$ Benzoylhistidine was measured by HPLC on a reversedphase column. The reaction mixtures were put on a Develosil ODS-5 column $(4.6 \times 250 \mathrm{~mm})$ and eluted with $25 \%$ methanol in $0.1 \%$ trifluoroacetic acid at a rate of $0.8 \mathrm{ml} / \mathrm{min}$, being monitored by absorbance at $230 \mathrm{~nm}$. Areas of the chromatographic peaks of each materials were calculated by a Shimadzu Chromatopac Integrator C-R3A.

Reaction of the tryptophan derivative with $\mathrm{Fe}(\mathrm{II}) /$ EDTA/ascorbate. Reaction mixtures $(10 \mathrm{ml})$ in phosphate buffer (pH 7.2) containing $1 \mathrm{~mm} N$-t-butoxycarbonyl-L-tryptophan, $5 \mathrm{~mm}$ ascorbate, $50 \mu \mathrm{M} \mathrm{FeSO}_{4}$, and $50 \mu \mathrm{m}$ EDTA were incubated at room temperature. Both substrate and products were measured by HPLC on a reversed-phase column. The reaction mixture was put on a Develosil ODS- 5 column $(4.6 \times 250 \mathrm{~mm})$ equilibrated in a solution of $30 \%$ methanol in $0.05 \mathrm{~m}$ ammonium acetate at a flow rate of $0.8 \mathrm{ml} / \mathrm{min}$. Products were detected by absorbance at $210 \mathrm{~nm}$. Areas of the chromatographic peaks of each materials were calculated by a Shimadzu Chromatopac Integrator C-R3A.

Assay of the hydroxyl radical. The hydroxyl radical was assayed by an adaptation of the method of Aruoma et al. ${ }^{19}$ The reaction contained, in a final volume of $10 \mathrm{ml}$ of $0.1 \mathrm{M}$ phosphate buffer, $\mathrm{pH} 7.2,5 \mathrm{~mm}$ ascorbate, $50 \mu \mathrm{M}$ $\mathrm{FeSO}_{4}, 50 \mu \mathrm{M}$ EDTA, and $1 \mathrm{~mm}$ deoxyribose. The reaction mixture was incubated at room temperature. After incubation, $1.0 \mathrm{ml}$ of $2.8 \%$ trichloroacetic acid and $1.0 \mathrm{ml}$ of $1 \%(\mathrm{w} / \mathrm{v})$ 2-thiobarbituric acid in $0.05 \mathrm{M} \mathrm{NaOH}$ were added to $2 \mathrm{ml}$ of the reaction mixture, and the samples were boiled for $10 \mathrm{~min}$, then cooled. The absorbance at $532 \mathrm{~nm}$ was measured. The malondialdehyde was calculated based upon a molar extinction coefficient of $1.65 \times 10^{5}$. 


\section{Results}

Oxidative modification of the protein by $\mathrm{Fe}(\mathrm{II}) /$ EDT A/ascorbate

Time dependent alteration of bovine serum albumin during incubation with $50 \mu \mathrm{M} \mathrm{Fe}(\mathrm{II})$, $50 \mu \mathrm{M}$ EDTA, and $5 \mathrm{~mm}$ ascorbate was examined by polyacrylamide gel electrophoresis (Fig. 1). There was a general increase in acidity following exposure to $\mathrm{Fe}(\mathrm{II}) / \mathrm{EDTA} /$ ascorbate. Whether this effect resulted from a loss of basic groups, the formation of new acidic groups, or a combination of the two is uncertain, but active species generated by $\mathrm{Fe}(\mathrm{II}) / \mathrm{EDTA} /$ ascorbate gave rise to some chemical modifications of the amino acid residues of the protein.

Hence, we examined the site of damage of the protein, since ${ }^{\circ} \mathrm{OH}$ generation at a site-

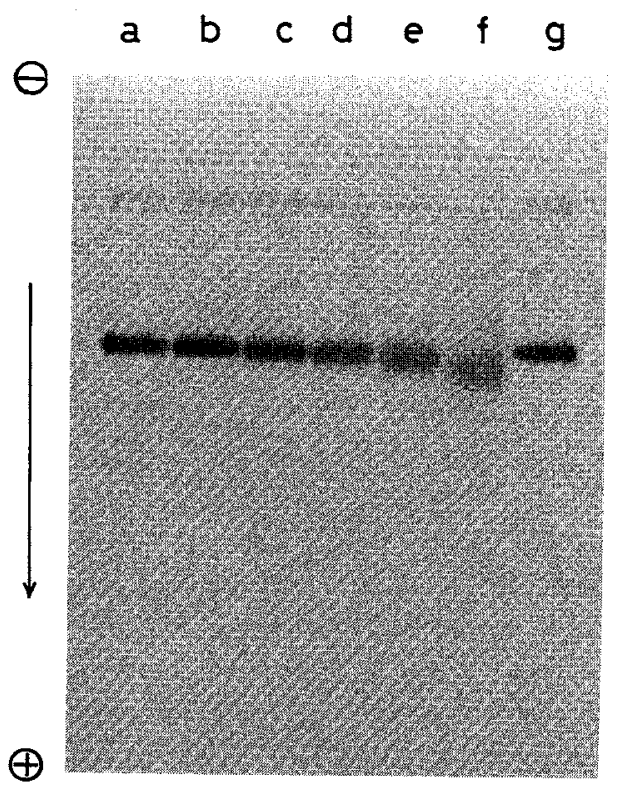

Fig. 1. Polyacrylamide Gel Electrophoresis of Bovine Serum Albumin Exposed to Fe(II)/EDTA/Ascorbate.

The reaction mixtures contained $0.04 \%$ bovine serum albumin, $5 \mathrm{~mm}$ ascorbate, $50 \mu \mathrm{M} \mathrm{Fe}(\mathrm{II})$, and $50 \mu \mathrm{M}$ EDTA in $0.1 \mathrm{M}$ phosphate buffer $(2.5 \mathrm{ml}, \mathrm{pH} 7.2)$, and $0.15 \mathrm{ml}$ portions of the mixtures were put on each time $(0,1,2,4$, 8 , and $24 \mathrm{hr}$ ). After the addition of $0.05 \mathrm{ml}$ of glycerol containing $0.01 \%$ bromphenol blue, the mixtures were used for polyacrylamide gel electrophoresis. Lanes a and g, zero time; lane b, $1 \mathrm{hr}$; lane c, $2 \mathrm{hr}$; lane d, $4 \mathrm{hr}$; lane e, $8 \mathrm{hr}$; lane f, $24 \mathrm{hr}$. specific location on the protein molecule has been suggested in metal-catalyzed free radical systems. ${ }^{18)}$ To find which amino acid residues of the protein are involved in the $\mathrm{Fe}(\mathrm{II}) / \mathrm{EDTA} /$ ascorbate-dependent reactions, bovine serum albumin was treated with $\mathrm{Fe}(\mathrm{II}) / \mathrm{EDTA} /$ ascorbate, hydrolyzed with $6 \mathrm{~N}$ $\mathrm{HCl}$, and then used for amino acid analysis. Table I shows that the acid hydrolysis and amino acid analysis. Table I shows that the acid hydrolysis and amino acid analysis found no difference in the amino acid content, other than histidine residues $(26.4 \%)$, of native and modified protein. However, the fluorescence excitation and emission spectra of the protein showed a marked decrease of the tryptophan content (Fig. 2). Cysteine and methionine residues are likely candidates for oxidative modification, but analysis of the acid hydrolysate found no difference in their contents. Con-

Table I. Changes in Amino Acid Compositions of Bovine SERUM Albumin DURING INCUBATION WITH $\mathrm{Fe}(\mathrm{II}) /$ EDTA/AsCORBATE $^{a}$

\begin{tabular}{lrrrr}
\hline & \multicolumn{4}{c}{ Molar ratio $(\%)^{b}$} \\
\cline { 2 - 5 } Amino acid & \multicolumn{4}{c}{ } \\
\cline { 2 - 5 } & $0 \mathrm{hr}$ & $4 \mathrm{hr}$ & $8 \mathrm{hr}$ & $24 \mathrm{hr}$ \\
\hline Asp & 9.6 & 9.3 & 9.5 & 9.5 \\
Thr & 5.5 & 5.4 & 5.5 & 5.6 \\
Ser & 4.0 & 3.7 & 3.9 & 4.0 \\
Glu & 14.3 & 14.2 & 14.0 & 14.6 \\
Pro & 8.1 & 7.9 & 8.1 & 7.8 \\
Gly & 2.9 & 3.0 & 2.8 & 3.0 \\
Ala & 7.6 & 7.3 & 7.4 & 7.4 \\
Cys & 2.0 & 2.4 & 2.0 & 2.0 \\
Val & 6.7 & 6.8 & 6.6 & 6.6 \\
Met & 0.7 & 0.8 & 0.7 & 0.8 \\
Ileu & 2.2 & 2.4 & 2.2 & 2.2 \\
Leu & 10.5 & 10.6 & 10.2 & 11.0 \\
Tyr & 3.4 & 3.1 & 3.3 & 3.2 \\
Phe & 4.7 & 4.5 & 4.6 & 4.8 \\
His & 3.8 & 3.4 & 3.1 & 2.8 \\
Lys & 10.2 & 10.6 & 10.0 & 10.1 \\
Arg & 4.1 & 4.2 & 4.1 & 4.1 \\
\hline
\end{tabular}

a Reactions were done in phosphate buffer $(2.5 \mathrm{ml}$ total volume), pH 7.2 , containing $0.04 \%$ protein, $5 \mathrm{~mm}$ ascorbate, $50 \mu \mathrm{M} \mathrm{FeSO}$, and $50 \mu \mathrm{m}$ EDTA at room temperature

b Molar ratio (\%) was represented by the molar concentration of each amino acid per total amino acid. 


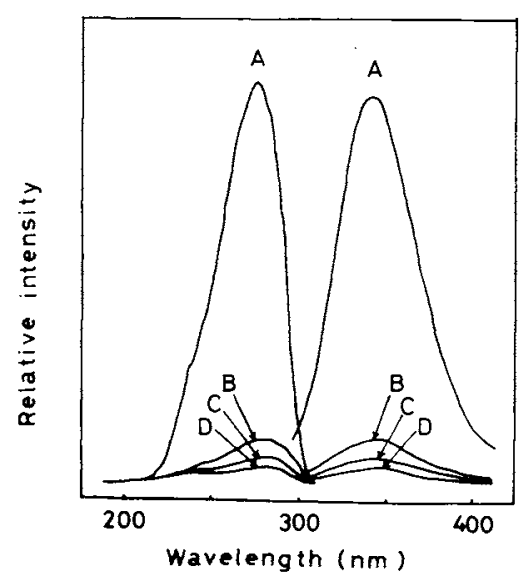

Fig. 2. Time-Dependent Changes in the Fluorescent Properties of Bovine Serum Albumin during Incubation with $\mathrm{Fe}(\mathrm{II}) / \mathrm{EDTA} /$ Ascorbate.

The substrate $(0.04 \%)$ in $0.1 \mathrm{M}$ phosphate buffer $(\mathrm{pH} 7.2)$ was exposed to the Fe(II)/EDTA/ascorbate system composed of $5 \mathrm{~mm}$ ascorbate, $50 \mu \mathrm{M} \mathrm{FeSO}_{4}$, and $50 \mu \mathrm{M}$ EDTA. Incubation: A, $0 \mathrm{hr} ; \mathrm{B}, 4 \mathrm{hr} ; \mathrm{C}, 8 \mathrm{hr} ; \mathrm{D}, 24 \mathrm{hr}$.

sidering these results, the oxidative modification of the serum albumin induced by $\mathrm{Fe}$ (II)/ EDTA/ascorbate involves aiteration of specific amino acid residues such as histidine and tryptophan.

\section{Effects of the hydroxyl radical scavengers}

It is definite that some active free radical species generated by $\mathrm{Fe}$ (II)/EDTA/ascorbate causes these structural alterations of the protein. Actually, mannitol and dimethylsulfoxide, well-known ${ }^{\circ} \mathrm{OH}$ scavengers, significantly suppressed the modification of the protein (Table II). Therefore, the evidence was found to implicate ${ }^{\circ} \mathrm{OH}$-dependent free radical reactions, while, in contrast, the ${ }^{\circ} \mathrm{OH}$ scavengers tested (mannitol and dimethylsulfoxide) failed to provide any protection from the oxidative modification of the protein by $\mathrm{Cu}$ (II)/ascorbate (Table II). This is a serious difference between the Fe(II)/EDTA/ascorbate and the $\mathrm{Cu}$ (II)/ascorbate systems.

The results (Table II) led to the assumption that the mechanism of $\mathrm{Fe}(\mathrm{II}) / \mathrm{EDTA} /$ ascorbate is basically distinct from that of $\mathrm{Cu}(\mathrm{II})$ ascorbate. With respect to the reaction of metal/ascorbate with protein, we have report-
Table II. EFfECTS OF THE HYDROXYL RADICAL Scavengers on the Oxidative Modification of Bovine Serum Albumin by Fe(II)/EDTA/ AsCorbate AND Cu(II)/AsCORBATE ${ }^{a}$

\begin{tabular}{|c|c|c|c|}
\hline \multirow{2}{*}{ Addition } & \multirow{2}{*}{ Concentration $^{b}$} & \multicolumn{2}{|c|}{$\%$ Inhibition ${ }^{c}$} \\
\hline & & $\mathrm{Fe}(\mathrm{II}) / \mathrm{EDTA}$ & $\mathrm{Cu}(\mathrm{HI})$ \\
\hline None & - & 0 & 0 \\
\hline Dimethylsulfoxide & $10 \mathrm{~mm}$ & 42 & 4 \\
\hline Mannitol & $10 \mathrm{~mm}$ & 59 & 1 \\
\hline
\end{tabular}

a The reactions were done at room temperature, the solutions containing $0.04 \%$ bovine serum albumin, $5 \mathrm{~mm}$ ascorbate, and $50 \mu \mathrm{M} \mathrm{Fe}(\mathrm{II}) / \mathrm{EDTA}$ or $\mathrm{Cu}(\mathrm{II})$ in phosphate buffer $(2.5 \mathrm{ml}, \mathrm{pH} 7.2)$. Oxidation of the protein was detected by HPLC on a TSK-GEL G3000 SW column.

b All concentrations shown are final reaction concentrations.

c The percentage of inhibition is expressed as the inhibition rate of the decrease of the protein peak height on the chromatogram after $24 \mathrm{hr}$ of incubation.

ed that the $\mathrm{Cu}(\mathrm{II})$-dependent system gave rise to selective damage to histidine residues, ${ }^{13,14}$ ) and the data have been explained by the ligand formation of histidine with $\mathrm{Cu}$ (II) ion. The imidazole ring acts in ligand formation with $\mathrm{Cu}(\mathrm{II})$ which might induce the oxidative reaction due to oxygen radicals generated at a site-specific location on the protein molecule. Therefore, lack of inhibition by ${ }^{\circ} \mathrm{OH}$ scavengers of the $\mathrm{Cu}(\mathrm{II}) /$ ascorbate system has been explained by this site-specific mechanism. But in the Fe(II)/EDTA/ascorbate system, we speculate that $\mathrm{Fe}$ (II) ion chelated EDTA reacts with ascorbate without ligand formation with the target molecule (protein) and, therefore, the site of generation of active species is not so restricted as that on the $\mathrm{Cu}(\mathrm{II}) /$ ascorbate system. It seems probable that selective damage to tryptophan and histidine residues by $\mathrm{Fe}$ (II)/EDTA/ascorbate is due to their reactivity with $\mathrm{OH}$; however, the details remain to be further investigated.

\section{Reaction of the histidine residue analogue with $\mathrm{Fe}(I I) / E D T A /$ ascorbate}

We have measured the reactivity of $\mathrm{Fe}(\mathrm{II}) / \mathrm{EDTA} /$ ascorbate to the histidine de- 


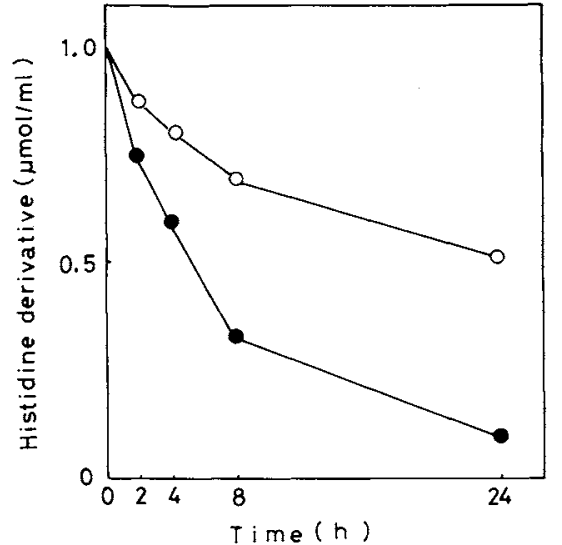

Fig. 3. Reactivity of $\mathrm{Fe}(\mathrm{II}) / \mathrm{EDTA} / \mathrm{Ascorb}$ ate and $\mathrm{Cu}(\mathrm{II}) /$ Ascorbate toward the Histidine Residues Analogue.

The reaction mixture in $0.1 \mathrm{M}$ phosphate buffer $(10 \mathrm{ml}$ total volume), $\mathrm{pH} 7.2$, containing $1 \mathrm{mM} N$-benzoylhistidine, $5 \mathrm{~mm}$ ascorbate, and $50 \mu \mathrm{M} \mathrm{Fe}$ (II)/EDTA or $\mathrm{Cu}(\mathrm{II})$ was incubated at room temperature. Chromatographic conditions are as follows: column, Develosil ODS-5 (4.6× $250 \mathrm{~mm}$ ); eluate, $0.1 \%$ trifluoroacetic acid-methanol (4:1); flow rate, $0.8 \mathrm{ml} / \mathrm{min}$; detection, absorbance at $230 \mathrm{~nm}$. Symbols: $O-\mathrm{O}, \quad \mathrm{Fe}(\mathrm{II}) / \mathrm{EDTA} / \mathrm{ascorb}$ ate; -O, $\mathrm{Cu}(\mathrm{II}) /$ ascorbate.

rivative ( $N$-benzoylhistidine), compared with $\mathrm{Cu}(\mathrm{II}) /$ ascorbate, and it was much lower (Fig. 3). As for products, the reaction of $\mathrm{N}$ benzoylhistidine with $\mathrm{Fe}(\mathrm{II}) / \mathrm{EDTA} /$ ascorbate resulted in the loss of the substrate $(49 \%)$ and, within $24 \mathrm{hr}$ of incubation, a number of products have been detected in low yields (data not shown). They were found to be identical to $N$-benzoylasparagine, $N$-benzoy- $\beta$-(2-oxo-imidazolonyl)alanine, benzamide, $N$-benzoylaspartylurea, $N$-benzoylaspartic acid, $N$-benzoyl- $N^{\prime}$-formylasparagine, 5-(2-benzamidovinyl)imidazole, and benzoate isolated by the reaction of $\mathrm{N}$-benzoylhistidine with $\mathrm{Cu}$ (II)/ascorbate. ${ }^{20,21)}$

\section{Reaction of the tryptophan residue analogue with $\mathrm{Fe}(\mathrm{II}) / \mathrm{EDT}$ A/ascorbate}

When the substrate ( $N$-benzoylhistidine) was replaced by $N$ - $t$-butoxycarbonyl-L-tryptophan, it became apparant that the tryptophan derivative was more reactive with the $\mathrm{Fe}(\mathrm{II}) / \mathrm{EDTA} /$ ascorbate system than the

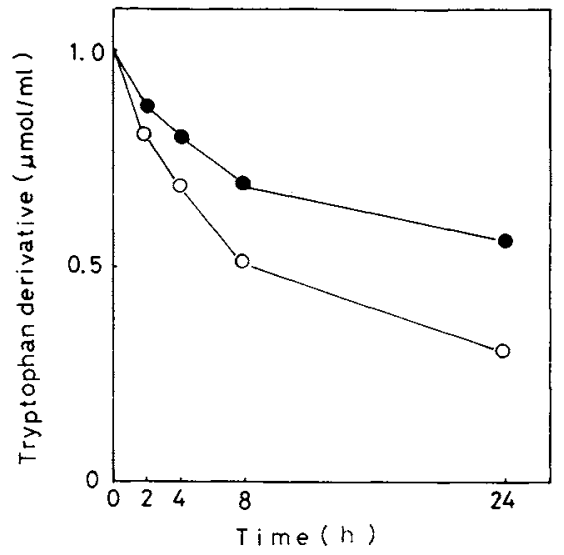

Fig. 4. Reactivity of $\mathrm{Fe}(\mathrm{II}) / \mathrm{EDTA} / \mathrm{Ascorb}$ ate and $\mathrm{Cu}(\mathrm{II}) /$ Ascorbate toward the Tryptophan Residues Analogue.

The reaction mixture in $0.1 \mathrm{M}$ phosphate buffer $(10 \mathrm{~m} 1$ total volume), $\mathrm{pH} 7.2$, containing $1 \mathrm{~mm} N$ - $t$-butoxycarbony-Ltryptophan, $5 \mathrm{~mm}$ ascorbate, $50 \mu \mathrm{M}$ Fe(II)/EDTA or Cu(II) was incubated at room temperature. Chromatographic conditions are as follows: column, Develosil ODS-5 (4.6× $250 \mathrm{~mm}$ ); eluate, $0.05 \mathrm{M}$ ammonium acetate-methanol (7:3); flow rate, $0.8 \mathrm{ml} / \mathrm{min}$; detection, absorbance at $210 \mathrm{~nm}$. Symbols: $\mathrm{O}-\mathrm{O}, \mathrm{Fe}(\mathrm{II}) / \mathrm{EDTA} / \mathrm{ascorb}$ ate; - $-\mathrm{Cu}$ (II)/ascorbate

$\mathrm{Cu}(\mathrm{II}) /$ ascorbate system (Fig. 4). Approximately $66 \%$ of the substrate was lost after $24 \mathrm{hr}$ and, instead, a number of newly formed products have been detected. However, their individual yields, based on the substrate, were approximately $5 \sim 10 \%$ at $24 \mathrm{hr}$ of incubation (data not shown). Isolation and structural elucidation of products are under way and will be presented elsewhere.

Similarly to the result in Table II, the reaction of $\mathrm{Fe}$ (II)/EDTA/ascorbate toward the tryptophan derivative was significantly suppressed by ${ }^{\circ} \mathrm{OH}$ scavengers (dimethylsulfoxide and mannitol) (data not shown). Furthermore, the formation of ${ }^{\circ} \mathrm{OH}$ from $\mathrm{Fe}(\mathrm{II}) / \mathrm{EDTA} /$ ascorbate was measured by the method of Aruoma et al. ${ }^{19)}$ Figure 5 illustrates the formation of ${ }^{\circ} \mathrm{OH}$ as thiobarbituric acid-reactive products following the incubation of deoxyribose with $\mathrm{Fe}(\mathrm{II}) / \mathrm{EDTA} /$ ascorbate. The extent of free radical formation by $\mathrm{Fe}(\mathrm{II}) / \mathrm{EDTA} / \mathrm{ascorb}$ ate was markedly reduced by increasing concentrations of the tryp- 


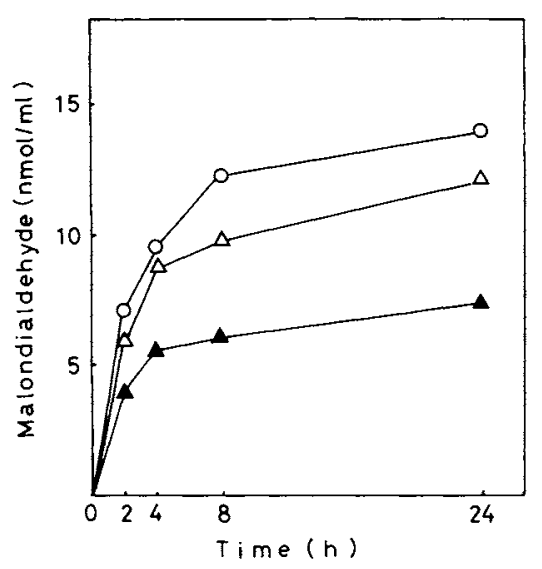

Fig. 5. Assay of the Hydroxyl Radical Generated by Fe(II)/EDTA/Ascorbate Using 2-Deoxyribose as the Substrate.

The reaction mixture containing $1 \mathrm{~mm}$ 2-deoxyribose, $5 \mathrm{mM}$ ascorbate, $50 \mu \mathrm{M} \mathrm{FeSO}$, and $50 \mu \mathrm{M}$ EDTA in a final volume of $10 \mathrm{ml}$ of $0.1 \mathrm{M}$ phosphate buffer, $\mathrm{pH} 7.2$, was incubated in the presence and absence of the tryptophan derivative $(\mathrm{O}-\mathrm{O}, 0 \mathrm{~mm} ; \triangle-\triangle, 1 \mathrm{~mm} ; \mathbf{\Delta}-\mathbf{\Delta}, 10 \mathrm{~mm})$.

tophan derivative. This means that the tryptophan residue analogue is susceptible to the reaction of ${ }^{\circ} \mathrm{OH}$ and competitive with another vulnerable substrate (2-deoxyribose).

\section{Discussion}

The iron(II)/EDTA/ascorbate system called the Udenfriend system is a well-known hydroxylating reagent. This system consists of ascorbate, $\mathrm{Fe}(\mathrm{II})$, a chelating agent (EDTA), and oxygen, which under physiological conditions of temperature and $\mathrm{pH}$ hydroxylates organic substances in a manner shown to be closely analogous to in vivo hydroxylations. ${ }^{22,23)}$ The hydroxyl radical $(\mathrm{OH})$ has been regarded as the active species in this system.

The hydroxyl radical is an extremely reactive species that oxidizes cellular constituents or added agents via direct addition (e.g., ring-hydroxylation), hydrogen atom abstraction, and electron transfer. It has been found that a great many biologically relevant compounds have second order reaction rate constants of $10^{9} \sim 10^{10} \mathrm{M}^{-1} \mathrm{sec}^{-1}$ which con- stitute essentially diffusion-limited reactivity. ${ }^{24,25)}$ It is generally believed that an indiscriminate attack on membranes, proteins, essential sulfydryl groups, and other tissue constitutents, is a major reason for tissue damage during $x$-irradiation, ${ }^{26)}$ during exposure in vivo to ${ }^{\circ} \mathrm{OH}$-generating cellular toxins, ${ }^{27)}$ or in the presence of ${ }^{\circ} \mathrm{OH}$-generating biochemical systems in vivo. ${ }^{28)}$ Evidence for the existence of ${ }^{\circ} \mathrm{OH}$ in biochemical systems has been based on the identification of products formed when 'OH attacks an exogenous compound added in high concentration.

The results obtained in this study clearly reveal that ${ }^{\circ} \mathrm{OH}$ generated by $\mathrm{Fe}(\mathrm{II}) / \mathrm{EDTA} /$ ascorbate is highly reactive and specific to tryptophan residues of the protein. It has been noted that tryptophan is the most vulnerable amino acid to free radical oxidations, ${ }^{29}$ ) and the results agree with known rate constants for reaction of tryptophan with ${ }^{\circ} \mathrm{OH}{ }^{25}$ ) Therefore, it seems probable that the highest reactivity of tryptophan residues of the protein is due to their intrinsic reactivity with the active species $(\mathrm{OH})$.

On the other hand, for the oxidation of tryptophan residues of protein by iron-redox system, Levine ${ }^{10)}$ and Kim et al. ${ }^{30)}$ have measured the change in tryptophan contents of glutamine synthetase, and they have confirmed that the tryptophan residues of modified protein were not altered. These results are seriously different from our results. Although the reason remains unclear, it is probable that the primary, secondary, and tertiary structure of protein can influence the reactivity of tryptophan residues with ${ }^{\circ} \mathrm{OH}$ generated by iron-redox systems.

The oxidation chemistry of tryptophan and its derivatives is interesting because it is recognized that the indole ring in tryptophan residues is susceptible to oxidation. The formation of $\mathrm{N}$-formylkynurenine and kynurenine was confirmed on radiolysis, ${ }^{31)}$ photooxidation, ${ }^{32)}$ and reaction with lipid hydroperoxide. ${ }^{33)}$ In metal-catalyzed oxidation systems coupled with $\mathrm{H}_{2} \mathrm{O}_{2}$, the oxidative inactivation of superoxide dismutase was report- 
ed, ${ }^{34 \sim 36)}$ and the formation of kynureninelike compounds has been suggested. ${ }^{36)}$ Oxidized products of tryptophan can contribute to the development of yellow and brown cataracts in the human lens, and, moreover, $\mathrm{N}$ formylkynurenine and kynurenine are suspected to be promoters of urinary bladder carcinogenesis in mice. ${ }^{37}$ In addition, these specific reactions of tryptophan might affect the activity of the enzymes which require it for their functions.

These results demonstrate that ${ }^{\circ} \mathrm{OH}$ generated by the iron-redox system can essentially modify the protein primary structure. Such modification to primary structure underlie the alteration of secondary and tertiary structure of protein. In relation to this, it has been noted that oxidative modification of primary, secondary, and tertiary structure commonly coincides with increased proteolytic susceptibility. ${ }^{38)}$

The occurence of similar specific reactions to protein is suggested in vivo when the free radical reactions are initiated by iron(II) and ascorbate. It is definite that the formation of ${ }^{\circ} \mathrm{OH}$ gives rise to selective oxidation of tryptophan residues of protein. Such reactions may therefore be physiologically important in connection with oxygen toxicity and protein turnover in mixed-function oxidation systems.

Based on this study, we are now trying to characterize the oxidation product of the tryptophan residues analogue chemically to establish the mechanism of the reaction of ${ }^{\circ} \mathrm{OH}$ with tryptophan residues of proteins.

\section{References}

1) S. Lewin, "Biological Activity and Potential," in Vitamin C: Its Molecular Biology and Medical Potential, Academic, London, 1976, pp. $75 \sim 103$.

2) C. J. Bates, "The Function and Metabolism of Vitamin C in Man," in Vitamin C (Ascorbic Acid), ed. by J. N. Counsell and D. H. Hornig, Applied Science, London, 1981, p. 1.

3) B. H. J. Bielski, "Chemistry of Ascorbic Acid Radicals," in Ascorbic Acid: Chemistry, Metabolism, and Uses, ed. by P. A. Seib and B. M. Tolbert, American Chemical Society, Washington, D.C., 1982, pp. $81 \sim 100$.
4) M. M. T. Khan and A. E. Martell, J. Am. Chem. Soc., 89, 4176 (1967).

5) M. M. T. Khan and A. E. Martell, J. Am. Chem. Soc., 89, 7104 (1967).

6) Y. Ogata, Y. Kosugi and T. Morimoto, Tetrahedron, 24, 4057 (1968).

7) A. Samuni, J. Aronovitch, D. Godinger, M. Chevion and G. Czapski, Eur. J. Biochem., 137, 119 (1983).

8) K. Uchida and S. Kawakishi, Agric. Biol. Chem., 50, 2579 (1986).

9) E. Shinar, T. Navok and M. Chevion, J. Biol. Chem., 258, 14778 (1983)

10) R. L. Levine, J. Biol. Chem., 258, 11823 (1983).

11) R. L. Levine, Methods Enzymol., 107, 370 (1984).

12) G. Marx and M. Chevion, Biochem. J., 236, 397 (1985).

13) K. Uchida and S. Kawakishi, Agric. Biol. Chem., 52, 1529 (1988).

14) K. Uchida and S. Kawakishi, J. Agric. Food Chem., 37, 897 (1989).

15) S. H. Chiou, J. Biochem., 94, 1259 (1983).

16) K. Uchida, M. Mitsui and S. Kawakishi, Biochim. Biophys. Acta, 991,377 (1989).

17) B. J. Davis, Ann. N. Y. Acad. Sci., 121, 404 (1964).

18) J. M. C. Gutteridge and S. Wilkins, Biochim. Biophys. Acta, 759, 38 (1983).

19) O. I. Aruoma, M. Grootveld and B. Halliwell, $J$. Inorg. Biochem., 29, 289 (1987).

20) K. Uchida and S. Kawakishi, Biochem. Biophys. Res. Commun., 138, 659 (1986).

21) K. Uchida and S. Kawakishi, Bioorg. Chem., 17, 330 (1989).

22) S. Udenfriend, C. T. Clark, J. Axelrod and B. B. Brodie, J. Biol. Chem., 208, 731 (1954).

23) B. B. Brodie, J. Axelrod, P. A. Shore and S. Udenfriend, J. Biol. Chem., 208, 741 (1954).

24) N. Anbar and P. Neta, Int. J. Appl. Radiat. Isot., 18, 493 (1967)

25) L. M. Dorfman and G. E. Adams, National Standard Reference Data System, National Bureau of Standards 46, Washington D.C., 1973.

26) B. H. Bielski and J. M. Gebieki, in "Free Radical in Biology," ed. by W. A. Pryor, Vol. 3, Academic Press, New York, 1977, pp. $2 \sim 48$.

27) G. Chen, Photochem. Photobiol., 28, 669 (1978).

28) K. Brawn and I. Fridovich, Arch. Biochem. Biophys., 206, 414 (1981).

29) K. J. A. Davies, M. E. Delsignore and S. W. Lin, J. Biol. Chem., 262, 9902 (1987).

30) K. Kim, S. G. Rhee and E. R. Stadman, J. Biol. Chem., 260, 15394 (1985).

31) G. G. Jayson, G. Scholes and J. Weiss, Biochem. J., 57, 386 (1954).

32) P. Walrant, R. Santus and L. T. Grossweiner, Photochem. Photobiol., 22, 63 (1975).

33) M. K. Krogull and O. Fennema, J. Agric. Food Chem., 35, 66 (1987). 
34) E. K. Hodgson and I. Fridovich, Biochemistry, 24, 5294 (1975).

35) E. K. Hodgson and I. Fridovich, Biochemistry, 24, 5299 (1975).

36) F. Yamakura, Biochem. Biophys. Res. Commun., 122,
635 (1984).

37) M. Matsushima, S. Takao, E. Erturk and G. T. Bryan, Cancer Res., 42, 3587 (1982).

38) K. J. A. Davies, J. Biol. Chem., 262, 9895 (1987). 